\title{
Manumycin induces apoptosis in prostate cancer cells
}

This article was published in the following Dove Press journal:

OncoTargets and Therapy

22 May 2014

Number of times this article has been viewed

\author{
Jing-Gao $\mathrm{Li}^{1, *}$ \\ Miao-Rong She ${ }^{2, *}$ \\ Ci-Yong Lu $^{3}$ \\ Shan-Shan Wei ${ }^{2}$ \\ Ping-Fang $\mathrm{Xia}^{2}$ \\ Ze-Sheng $\mathrm{Lu}^{2}$ \\ Qi Peng ${ }^{2}$
}

'Department of Nephrology, Sun Yat-Sen Memorial Hospital, Sun Yat-Sen University, ${ }^{2}$ Department of Hematology, Guangdong General Hospital, Guangdong Academy of Medical Sciences, ${ }^{3}$ School of Public Health, Sun Yat-Sen University, Guangzhou, People's Republic of China

*These authors contributed equally to this work
Correspondence: Miao-Rong She Department of Hematology, Guangdong General Hospital, Guangdong Academy of Medical Sciences, 106 Zhongshan Er Road, Guangzhou, Guangdong 510080, People's Republic of China Tel +86 I37 I072 8I I2

Email shemiaorong@hotmail.com
Background: Manumycin exhibits an antitumor effect in a variety of cancer cell lines, including prostate cancer cell lines (DU145 and PC-3). Our previous studies demonstrated that manumycin induced the apoptosis of anaplastic thyroid cancer cells and leukemia cells via the intrinsic apoptosis pathway. In the current study, we further evaluated the effect of manumycin in two prostate cancer cell lines (LNCaP and 22Rv1), and here we elucidate some of the underlying mechanisms.

Materials and methods: The cell viability of prostate cancer cells was measured by 3-(4,5-dimethylthiazol-2-yl)-2,5-diphenyltetrazolium bromide assay after treatment with manumycin for 48 hours. Apoptosis was detected by flow cytometry using annexin $\mathrm{V}$ and propidium iodide. The expressions of B-cell lymphoma (Bcl)-2 family members and the activations of caspase- 9 and caspase- 3 were detected by Western blotting.

Results: Manumycin treatment resulted in significant decreases in the viabilities of the two prostate cancer cell lines in a dose-dependent manner through apoptosis, and this apoptosis involved caspase- 9 activation. A specific inhibitor of caspase- 9 protected cells from caspase-3 activation, apoptosis, and cytotoxicity induced by manumycin. We also found that manumycin downregulated Bcl-2 expression and upregulated Bax expression.

Conclusion: Our data suggest that manumycin induces apoptosis in prostate cancer cells through regulation of the Bcl-2 family involving caspase-9 activation. These results suggest that manumycin may be beneficial for the treatment of prostate cancer.

Keyword: Bcl-2, farnesyltransferase inhibitor, caspase-9, caspase-3, Bax

\section{Introduction}

Prostate cancer is the most common malignancy and the second-leading cause of cancer death in men in the US. ${ }^{1}$ The incidence and mortality rates of prostate cancer are low in Chinese men. However, prostate cancer incidence rates increase with age. The trend of aging men is rising gradually in the People's Republic of China (PRC). Therefore, the incidence rates of prostate cancer in Chinese males over the age of 70 ranked the first in the genitourinary tumor. ${ }^{2}$ The treatment options for patients include surgery, radiation therapy, hormonal therapy, chemotherapy, and combinations of some of these treatments. However, prostate cancer cells are only modestly responsive or even unresponsive to the cytotoxic effects of chemotherapy or radiation therapy. Consequently, there is a desperate need for new anticancer agents that are highly effective in inducing apoptosis in tumor cells.

Targeting of the signal-transduction pathway and inducing apoptosis have important roles in killing cancer cells. Ras is known to transduce important survival pathways in 
cancer cells. Mutations in Ras have been reported for many cancers, including prostate cancer. ${ }^{3}$ More recently, Ras has been shown to promote prostate cancer cell survival. Activation and translocation of Ras require farnesylation to allow its function in transducing the mitogenic signals of tyrosinekinase receptors. ${ }^{4}$ Inhibition of farnesyltransferase may block the survival pathway of prostate cancer. Manumycin, a farnesyltransferase inhibitor (FTI) that mimics the farnesyl pyrophosphate group, inhibits farnesyltransferase by competing with the farnesyl pyrophosphate substrate, and it has antitumor activity against a variety of cancers. ${ }^{5-7}$ The antineoplastic action of FTIs may involve multiple mechanisms: antiproliferative, proapoptotic, and antiangiogenic. ${ }^{8,9}$ Our previous studies showed that manumycin induced apoptosis in leukemia cells and anaplastic thyroid cancer cells through the mitochondrial apoptotic pathway. ${ }^{5,7}$ Moreover, manumycin induced apoptosis in prostate cancer cell lines (DU145 and $\mathrm{PC}-3) .{ }^{10}$

Apoptotic signaling events occur through multiple independent pathways, and are initiated by various extracellular and intracellular factors. The intrinsic pathway is initiated by the mitochondria, while the extrinsic pathway is initiated by cell-surface receptors. ${ }^{11}$ Mitochondria-mediated apoptosis occurs in response to a wide range of stimuli. ${ }^{12}$ Activation of procaspase- 9 to caspase-9 plays an important role in the execution of the mitochondrial apoptotic pathway. ${ }^{13}$ Furthermore, the B-cell lymphoma (Bcl)-2 family, including the antiapoptotic members Bcl-2 and Bcl-xL and the proapoptotic members Bax and Bad, is critical in apoptosis regulation. ${ }^{14}$ Apoptosis may be mediated by either downregulation of antiapoptotic proteins or upregulation of proapoptotic proteins. Inhibition of cell growth by a farnesyltransferase inhibitor (L-744 832) in prostate cancer cells is independent of the presence of the activation of Ras. ${ }^{15}$

Manumycin has been found to induce apoptosis in prostate cancer cell lines (DU145 and PC-3); however, any mechanisms involved in apoptosis induced by manumycin remain unexplored. Therefore, the human androgendependent prostate cancer cell line LNCaP and the androgen-independent prostate cancer cell line 22Rv1 were used to examine further the effects of manumycin on prostate cancer and any mechanisms involved in such effects.

In this study, we investigated the possibility that manumycin may activate caspase- 9 through regulating the Bcl-2 family. We hypothesized that manumycin can induce apoptosis in two prostate cancer cell lines (LNCaP and 22Rv1) through activation of caspase-9. Our results indicated that manumycin induced apoptosis in prostate cancer cells via downregulation of Bcl-2 and activation of caspase-9. Since FTIs have been shown to be relatively nontoxic in animal models and Phase I studies, ${ }^{16}$ these results support the evaluation of manumycin as a treatment in prostate cancer.

\section{Materials and methods Materials}

Manumycin, propidiumiodide(PI), dimethyl sulfoxide(DMSO; tissue-culture grade), and 3-(4,5-dimethylthiazol-2-yl)-2,5diphenyltetrazolium bromide (MTT) were purchased from Sigma-Aldrich (St Louis, MO, USA). Roswell Park Memorial Institute (RPMI) 1640 medium was purchased from Life Technologies (Carlsbad, CA, USA). Fetal bovine serum was purchased from HyClone (Logan, UT, USA). Anti-caspase-3 antibody, anti-caspase- 9 antibody, anti-Bcl-2 rabbit antibody, and anti-Bax rabbit antibody were purchased from Cell Signaling Technology (Danvers, MA, USA). $\beta$-Actin mouse monoclonal antibody was purchased from Boster Immunoleader (Fremont, CA, USA). Annexin V binding buffer and annexin $\mathrm{V}$ were purchased from BD Biosciences (San Jose, CA, USA). Manumycin, being lipophilic, was first dissolved in DMSO. The stock solution was diluted in tissue-culture medium at appropriate concentrations such that the final concentration of DMSO in culture medium would not exceed $0.1 \%$ (volume/volume $[\mathrm{v} / \mathrm{v}]$ ).

\section{Cell culture}

The human prostate cancer cell lines LNCaP and 22Rv1 from the American Type Culture Collection (Manassas, VA, USA) were maintained in RPMI 1640 medium supplemented with $10 \%$ heat-treated fetal bovine serum, penicillin (1\%), and streptomycin $(1 \%)$ at $37^{\circ} \mathrm{C}$ in a water-saturated atmosphere with $5 \% \mathrm{CO}_{2}$. All experiments were performed using exponentially growing cell cultures.

\section{Cytotoxicity assays}

Cell-growth inhibition or the relative number of viable cells was determined by MTT assay, as previously described. ${ }^{17}$ In brief, LNCaP or 22Rv1 cells were seeded onto 96-well plates at an initial density of 5,000 cells/well. After treatment for 48 hours, $20 \mu \mathrm{L}$ of MTT ( $3 \mathrm{mg} / \mathrm{mL}$ ) was added to each well, and the plates were incubated at $37^{\circ} \mathrm{C}$ for 4 hours. The cells were then centrifuged (700 $g$ for 15 minutes), and the medium was removed. The cell pellets were dissolved in $200 \mu \mathrm{L}$ of DMSO. Absorbance was measured at a wavelength of $570 \mathrm{~nm}$ with reference at wavelength $655 \mathrm{~nm}$. The percentage of viability was defined as $100 \%$ times the ratio of absorbance above the background in the sample to 
the average absorbance above the background in the control (DMSO-treated) samples. The background absorbance was measured in the wells with cells that had been killed by exposure to $70 \%$ ethanol for 10 minutes.

\section{Fluorescent flow-cytometric assay}

Flow-cytometric assays were performed at our Flow Cytometry Core Facility. Fluorescein isothiocyanate (FITC)-conjugated annexin V (BD Biosciences) and PI were used to detect cells undergoing apoptosis. In brief, cells were collected by centrifugation (200 $\mathrm{g}$ for $5 \mathrm{~min}$ utes at $4^{\circ} \mathrm{C}$ ) after experimental treatments. For staining, cells were washed twice with cold phosphate-buffered saline (PBS) and resuspended in $1 \times$ binding buffer at a concentration $1 \times 10^{6}$ cells $/ \mathrm{mL}$. Then, $100 \mu \mathrm{L}$ of solution was transferred to a $5 \mathrm{~mL}$ culture tube and $5 \mu \mathrm{L}$ of annexin V-FITC and $5 \mu \mathrm{L}$ of PI were added. Cells were gently vortexed and incubated in the dark for 15 minutes at room temperature. Prior to flow-cytometric analysis, $400 \mu \mathrm{L}$ of $1 \times$ binding buffer was added, and cells were analyzed on a FACSCaliburTM flow cytometer (BD Biosciences, San Jose, USA) using forward-scattered light versus side-scattered light as gating parameters.

\section{Preparation of total cell lysates}

After experimental treatments, cells floating in culture medium were pelleted by centrifugation. Cells that remained attached to the well were rinsed with PBS. Both the cell pellet and the cells attached to the well were then lysed in a total of $300 \mu \mathrm{L}$ of radioimmunoprecipitation-assay buffer (1× PBS, 1\% IGEPAL ${ }^{\circledR}$ CA-630 [Sigma-Aldrich], 0.5\% sodium deoxycholate, $0.1 \%$ sodium dodecyl sulfate [SDS], $0.1 \mathrm{mg} / \mathrm{mL}$ phenylmethylsulfonyl fluoride, and complete protease-inhibitor mix [one tablet per $50 \mathrm{~mL}$; Roche, Basel, Switzerland]) and combined together. The deoxyribonucleic acid in the lysate was sheared by sonication with eight 1 -second bursts at medium power.

\section{SDS-PAGE and immunoblotting}

SDS polyacrylamide gel electrophoresis (SDS-PAGE) was performed using standard methods. The protein concentrations of samples were measured using a modified Lowry method (DC ${ }^{\text {TM }}$ protein assay; Bio-Rad Laboratories, Hercules, CA, USA). Equal amounts of total protein $(30 \mu \mathrm{g} /$ well $)$ from each sample were loaded onto the SDS-PAG and transferred onto polyvinylidene fluoride membranes (Hybond-P; GE, Healthcare, Little Chalfont, UK). Kaleidoscope prestained standards (Bio-Rad) were used for molecular weight calibra- tion. Blocking was performed in $0.1 \%$ Tween $20(\mathrm{v} / \mathrm{v})$ and $5 \%$ nonfat milk in PBS. The membranes were incubated with anti-Bcl-2 rabbit antibody $(1: 1,500)$, anti-Bax rabbit antibody (1:1,000), anti-caspase-3 rabbit antibody $(1: 2,000)$, and anti-caspase-9 rabbit antibody $(1: 2,000)$, separately. The membranes were stripped and incubated with an anti- $\beta$-actin mouse monoclonal antibody $(1: 3,000)$ as a loading control. Expression of target protein was determined with horseradish peroxidase-conjugated antirabbit or antimouse immunoglobulin $\mathrm{G}(1: 3,000)$ and enhanced chemiluminescence (Thermo Fisher Scientific, Waltham, MA, USA), according to the manufacturer's suggested protocols. Kodak Xomatic AR film (Eastman Kodak, Rochester, NY, USA) was used to record the image generated by enhanced chemiluminescence using an Amersham ECL kit (GE Healthcare).

\section{Statistics}

Comparisons in experiments were performed using one-way analysis of variance (ANOVA) with Tukey's test or Student's $t$-test to assess the statistical significance of differences between groups. Differences with $P<0.05$ were considered significant.

\section{Results}

\section{Manumycin decreased the viability of prostate cancer cells}

After treatment with a range of concentrations of manumycin (0-64 $\mu \mathrm{mol} / \mathrm{L})$ for 48 hours, MTT data showed that manumycin significantly decreased viability in the prostate cancer cell lines $(P<0.05)$ (Figure 1). Modest degrees of cytotoxicity were noted at $8 \mu \mathrm{mol} / \mathrm{L}$ manumycin (48 hours), and near-maximal levels of cytotoxicity occurred at concentrations of greater than $32 \mu \mathrm{mol} / \mathrm{L}$.

\section{Manumycin induced apoptosis in prostate cancer cells}

To determine whether the cytotoxicity of manumycin involved apoptosis, we evaluated the apoptotic effect of manumycin in prostate cancer cells by flow cytometry for annexin $\mathrm{V}$ and PI staining. The time course of manumycin-mediated apoptosis in prostate cancer cells was analyzed (Figure 2). The percentage of early apoptotic cells (annexin $\mathrm{V}^{+} / \mathrm{PI}^{-}$) induced by manumycin treatment became apparent after 12 hours, and apoptosis was enhanced when drug-exposure time was elongated $(P<0.05)$. However, the late apoptotic cells (annexin $\mathrm{V}^{+} / \mathrm{PI}^{+}$) were increased after 15 hours, and became significant at 24 hours $(P<0.05)$. 


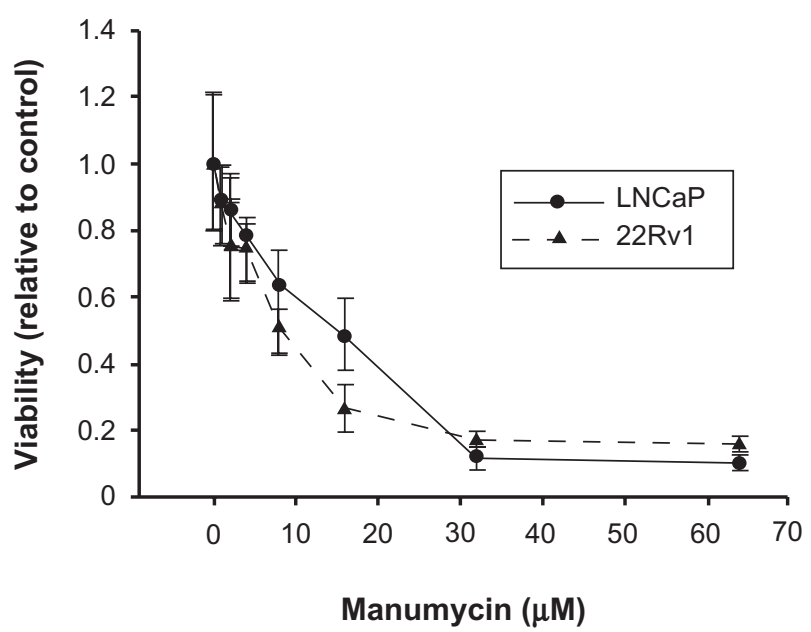

Figure I Cytotoxic effect of manumycin against LNCaP and 22RvI prostate cancer cell lines.

Notes: Cells were treated with $0-64 \mu \mathrm{mol} / \mathrm{L}$ manumycin for 48 hours. Cell viability was determined by 3-(4,5-dimethylthiazol-2-yl)-2,5-diphenyltetrazolium bromide assay. Mean viability relative to the control was plotted against the manumycin concentration. The error bars represent the $95 \%$ confidence intervals of three independent experiments.

\section{A}
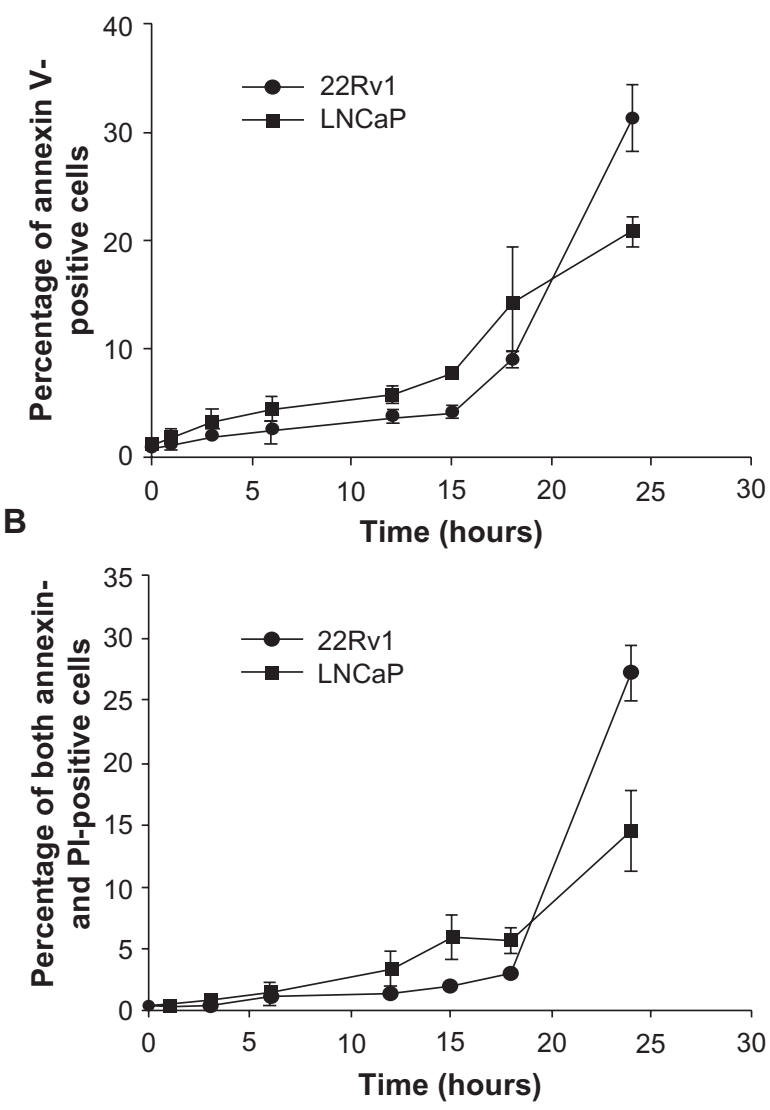

Figure 2 (A and $\mathbf{B}$ ) Effects of manumycin on apoptosis induction in LNCaP and $22 R v l$ prostate cancer cell lines.

Notes: Cells were treated with $32 \mu \mathrm{mol} / \mathrm{L}$ manumycin for different times. Cells were stained with annexin $\mathrm{V} /$ propidium iodide (PI), and apoptosis was determined by flow cytometry. (A) Time course of manumycin-mediated early stage of apoptosis (annexin $\mathrm{V}^{+} / \mathrm{PI}^{-}$) in $\mathrm{LNCaP}$ and $22 \mathrm{RvI}$ prostate cancer cell lines. (B) Time course of manumycin-mediated late stage of apoptosis or necrosis (annexin $\mathrm{V}^{+} / \mathrm{PI}^{+}$) in $\mathrm{LNCaP}$ and $22 \mathrm{RvI}$ prostate cancer cell lines.

\section{Manumycin induced activation of caspase- 9 and caspase-3 in prostate cancer cells}

The caspase-family proteins are important for apoptosis. Activation of caspase- 9 acts as the initiator of the intrinsic pathway of apoptosis. Therefore, we next investigated the activation of caspase-9. Cultured cells were divided into two treatment groups: DMSO (control) and $32 \mu \mathrm{mol} / \mathrm{L}$ manumycin. We found that manumycin caused activation of caspase-9 (increase in specific cleavage-activated caspase-9) in both cell lines (Figure 3). Activation of caspase-3 follows the activation of caspase-9. Therefore, we next investigated the activation of caspase-3. Similar to the results for caspase-9, manumycin caused activation of caspase-3 (decrease in pro-caspase- 3 and increase in specific cleavageactivated caspase-3) in both cell lines.

\section{Caspase-9 inhibitor blocked manumycin- induced apoptosis in prostate cancer cells}

We observed activation of caspase- 9 in the LNCaP and 22Rv1 cancer cells treated with manumycin. To investigate further whether the manumycin-induced apoptosis was mediated by the caspase-9 pathway, we used a caspase- 9 inhibitor to test the effect of manumycin on caspase- 3 activation. We found that manumycin significantly increased the activation of caspase- 3 compared with that in control cells (Figure 4A), whereas the

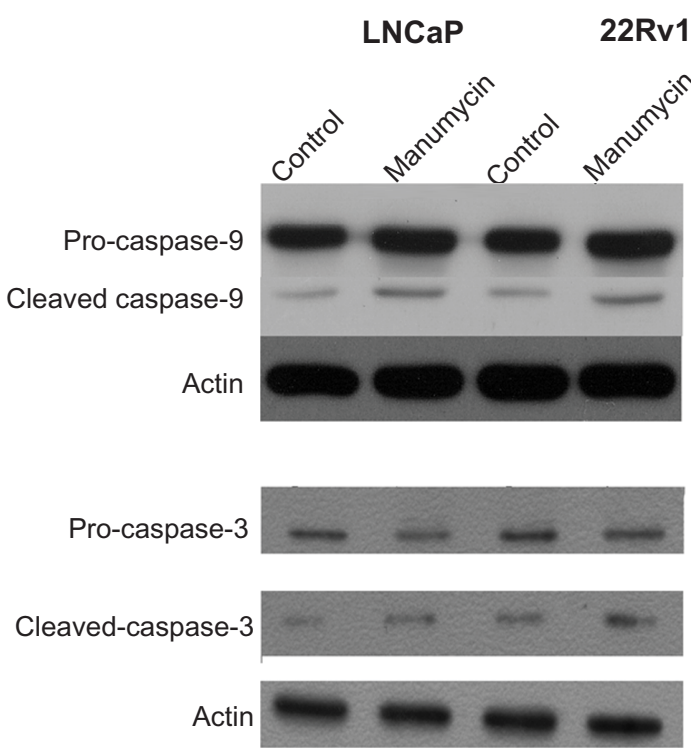

Figure 3 Manumycin induced activation of caspase- 9 and caspase- 3 in LNCaP and 22RvI prostate cancer cell lines.

Notes: Cells were treated with dimethyl sulfoxide (control) or $32 \mu \mathrm{mol} / \mathrm{L}$ manumycin for 16 hours. The cells were lysed and analyzed by Western blot, with specific antibodies against caspase- 9 or caspase-3. Both the inactive proenzymes of caspase- 9 and caspase- 3 and their respective active cleaved fragments are shown. The anti-actin immunoblot verifies equal loading. 
caspase- 9 inhibitor markedly decreased the activation of caspase- 3 by manumycin in both prostate cancer cell lines. These results indicated that caspase- 9 activation was required for induction of caspase- 3 activation by manumycin.

To confirm further that manumycin-induced apoptosis involved caspase-9, we tested the effect of the caspase- 9 inhibitor on apoptosis in prostate cancer cells. LNCaP and $22 \mathrm{Rv} 1$ cells were pretreated with the caspase-9 inhibitor for 2 hours prior to manumycin treatment. Apoptosis was then evaluated by annexin $\mathrm{V}$ and PI staining. Representative dual-fluorescence scatter diagrams for the LNCaP and 22Rv1 cells are shown in Figure 4B. The mean percentages of cells positive for annexin $\mathrm{V}$ only and for both annexin $\mathrm{V}$ and $\mathrm{PI}$ are plotted in the bar graphs in Figure $4 \mathrm{C}$ and D. As shown in Figure 4B-D, caspase-9 inhibitor significantly decreased early apoptosis and late apoptosis induced by manumycin in both cell lines $(P<0.05)$.
To investigate further whether the caspase- 9 inhibitor could protect prostate cancer cells from the cytotoxicity of manumycin, we measured the relative viability of cells treated for 48 hours with control, manumycin, the caspase- 9 inhibitor, or both manumycin and the caspase- 9 inhibitor. Concurrent treatment with the caspase-9 inhibitor significantly prevented a decrease in viability with manumycin treatment (Figure 4E) $(P<0.05)$. These results suggested that the large effect of manumycin on viability was mediated by caspase- 9 activation.

\section{Manumycin reduced $\mathrm{Bcl}-2$ expression and induced Bax upregulation in prostate cancer cells}

To investigate the intracellular mechanism for the apoptosis induced by manumycin in LNCaP and 22Rv1 cancer cells, we studied the expression of the proapoptotic Bax and
A

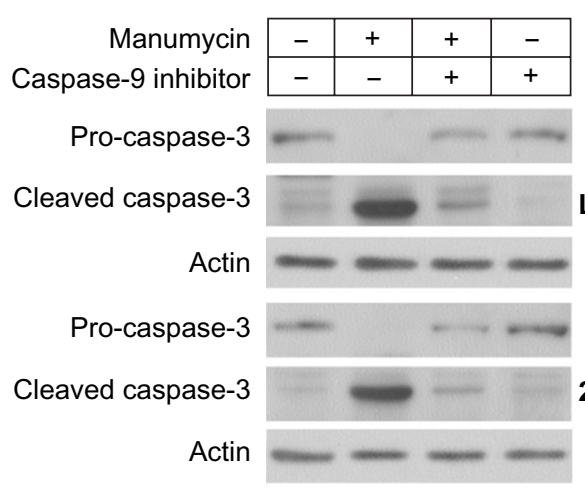

B

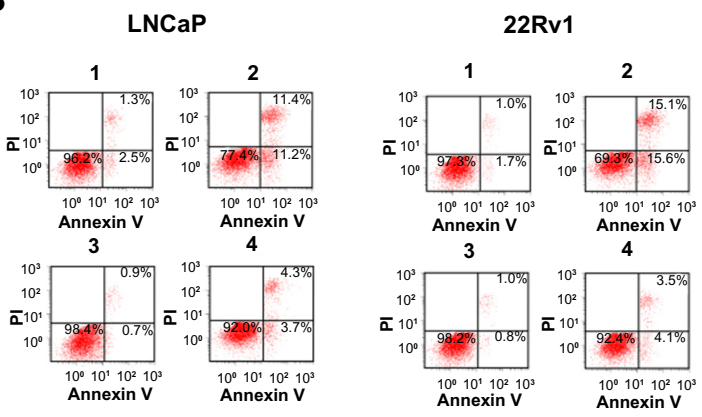

1 Control 2 Manumycin 3 Caspase-9 inhibitor 4 Caspase- 9 inhibitor + manumycin
C

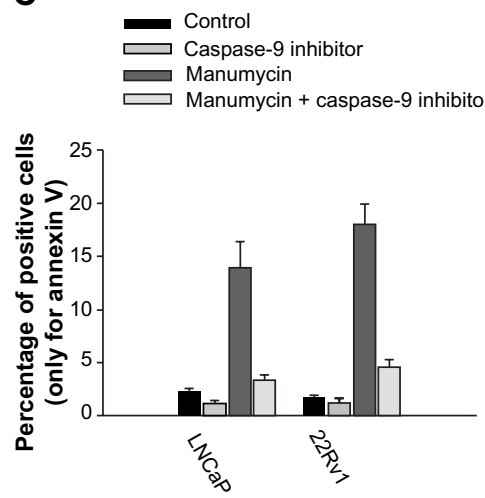

D



E



Figure 4 (A-E) Caspase-9 inhibitor blocked the effect of manumycin in prostate cancer cells.

Notes: (A) Caspase-9 inhibitor blocked caspase-3 activation induced by manumycin. Cells were treated with dimethyl sulfoxide (DMSO; control) or $32 \mu \mathrm{M}$ manumycin in the presence or absence of $50 \mu \mathrm{M}$ caspase- 9 inhibitor. The cells were lysed and analyzed by Western blot, with specific antibodies against caspase-3. Both the inactive proenzymes of caspase-3 and their respective active cleaved fragments are shown. The anti-actin immunoblot verifies equal loading. (B-D) Caspase-9 inhibitor blocked apoptosis induced by manumycin. Cells were treated with DMSO (control) or $32 \mu \mathrm{M}$ manumycin in the presence or absence of $50 \mu \mathrm{M}$ caspase-9 inhibitor. Caspase-9 inhibitor blocked the apoptosis induced by manumycin. (B) Representative two-dimensional scatter plots of annexin $\mathrm{V}$ versus propidium iodide (PI). (C) Average percentages of annexin V-positive cells only are presented in bar graphs. (D) Average percentages of both annexin V-positive and PI-positive cells are presented in bar graphs. (E) Caspase-9 inhibitor protected cells against the manumycin-induced decrease in cell viability. Cells were treated with DMSO (control), $32 \mu M$ manumycin, $50 \mu M$ caspase-9 inhibitor, or both $32 \mu \mathrm{M}$ manumycin and $50 \mu \mathrm{M}$ caspase-9 inhibitor for 48 hours. The results of three independent experiments are plotted.

Abbreviation: PI, propidium iodide. 
antiapoptotic $\mathrm{Bcl}-2$ proteins. We found that manumycin decreased the expression of Bcl-2 and increased the expression of Bax compared with untreated cells in both cell lines (Figure 5). These results indicated that the manumycininduced apoptosis in these prostate cancer cells was caused by downregulation of Bcl-2 and upregulation of Bax.

\section{Discussion}

This report provides evidence that manumycin induces apoptosis in prostate cancer cells. We demonstrated that manumycin downregulated Bcl-2 and upregulated Bax in prostate cancer cells, and we found that manumycin activated a mitochondrial pathway involving caspase- 9 and that a specific inhibitor of caspase- 9 protected cells from apoptosis. Taken together, our findings suggest that manumycininduced apoptosis in prostate cancer cells occurred through activation of caspase-9.

FTIs were developed as cancer therapeutics for both solid tumors and hematologic malignancies, and were initially designed to target oncogenic Ras. ${ }^{18,19}$ Our previous studies showed that manumycin induced apoptosis of anaplastic thyroid cancer cells and leukemia cells. ${ }^{5,7}$ Here, we demonstrated that manumycin decreased cell viability through apoptosis in both LNCaP and 22Rv1 prostate cancer cells. Apoptosis was detected using an annexin V/PI assay and Western blot analysis. Our results indicated that manumycin increased early and late-stage apoptosis in a time-dependent manner.

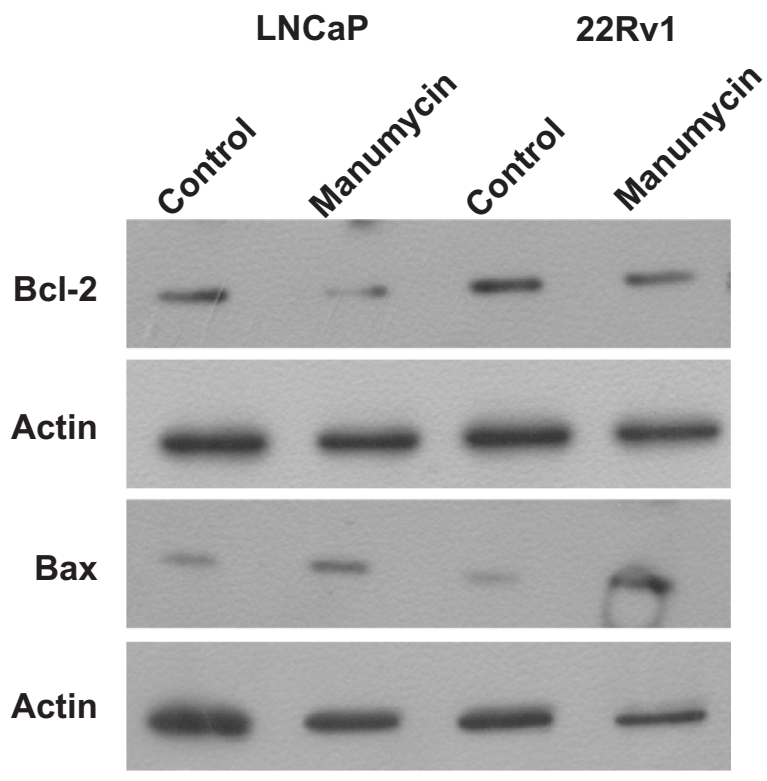

Figure 5 Effects of manumycin on expressions of B-cell lymphoma (Bcl)-2 and Bax in LNCaP and $22 \mathrm{Rv}$ l cells.

Notes: Cells were treated with dimethyl sulfoxide (control) or $32 \mu \mathrm{mol} / \mathrm{L}$ manumycin for 16 hours. The cells were lysed and analyzed by Western blot, with specific antibodies against Bcl-2 and Bax. The anti-actin immunoblot verifies equal loading.
Our data corroborate and extend the findings of induction of apoptosis in chronic myeloid leukemia stem/progenitor cells, breast cancer cells, and melanoma cells. ${ }^{8,20-23}$ A dysfunctional apoptotic pathway has been discovered in human cancers, and evasion of apoptosis contributes to the carcinogenesis of prostate cancer. ${ }^{24}$ Therefore, most conventional cancer therapies focus on the induction of apoptosis.

Apoptosis is tightly regulated by proapoptotic and antiapoptotic effector molecules, and can be mediated by several different pathways in response to various intrinsic and extrinsic signals. ${ }^{25}$ These signals affect the membrane potential of mitochondria, resulting in the activation of caspase-9 and subsequently caspase-3. The activation of caspase-3 leads to the apoptosis of cells. We found that manumycin increased the activation of caspase-9 and caspase-3. Furthermore, the caspase- 9 inhibitor significantly decreased the apoptosis induced by manumycin in both prostate cancer cell lines. These data confirmed that apoptosis induced by manumycin required caspase- 9 activation.

Bcl-2 family proteins, including proteins that suppress apoptosis (such as Bcl-2, Bcl-xL, and myeloid cell leukemia [Mcl]-1) and those that promote apoptosis (such as Bad, Bax, and Bid) play a critical role in regulating apoptosis. ${ }^{26}$ Bcl-2 and Bax are two members of the Bcl-2 protein family that regulate the balance between cell proliferation and apoptosis. ${ }^{27}$ Increased expressions of the antiapoptotic molecules Bcl-2, Bcl-xL, and Mcl-1 are associated with prostate cancer tumorigenesis, and inhibiting their expressions may induce tumor cells to undergo apoptosis. ${ }^{28}$ Our results showed that manumycin downregulated Bcl-2 and upregulated Bax in these prostate cancer cells. These results indicated the molecular events occurring during manumycininduced caspase-9-mediated apoptosis. However, the exact mechanisms by which manumycin induced the changes in Bcl-2 and Bax in these prostate cancer cells remain unclear and require further investigation.

In summary, in these prostate cancer cell lines, manumycin activated the intrinsic apoptotic pathway, with involvement of the Bcl-2 family as a signaling mediator. Our findings may help to elucidate the mechanisms underlying the efficacy of manumycin in prostate cancer cells and provide a new strategy for use against prostate cancer. However, more work is needed to establish the exact mechanism of manumycin activity in prostate cancer cells.

\section{Acknowledgments}

This research was supported by grants from the National Natural Science Foundation of China (81370664), 
the Guangdong Provincial Science and Technology Program (2011B061300033), and the Guangdong Provincial Traditional Chinese Medicine Administration Fund (20131103).

\section{Disclosure}

The authors report no conflicts of interest in this work.

\section{References}

1. Chornokur G, Dalton K, Borysova ME, Kumar NB. Disparities at presentation, diagnosis, treatment, and survival in African American men, affected by prostate cancer. Prostate. 2011;71(9):985-997.

2. Han SJ, Zhang SW, Chen WQ, Li CL. Analysis of the status and trends of prostate cancer incidence in China. Chin Clin Oncol. 2013;18(4): 330-334.

3. Wang XS, Shankar S, Dhanasekaran SM, et al. Characterization of KRAS rearrangements in metastatic prostate cancer. Cancer Discov. 2011;1(1):35-43.

4. Berndt N, Hamilton AD, Sebti SM. Targeting protein prenylation for cancer therapy. Nat Rev Cancer. 2011;11(11):775-791.

5. She M, Pan I, Sun L, Yeung SC. Enhancement of manumycin A-induced apoptosis by methoxyamine in myeloid leukemia cells. Leukemia. 2005;19(4):595-602.

6. Kim J, Seong J, Kim SH. Enhancement of tumor response by farnesyltransferase inhibitor in $\mathrm{C} 3 \mathrm{H} / \mathrm{HeJ}$ hepatocarcinoma. Ann $N Y$ Acad Sci. 2004;1030:95-102.

7. She M, Yang H, Sun L, Yeung SC. Redox control of manumycin A-induced apoptosis in anaplastic thyroid cancer cells: involvement of the xenobiotic apoptotic pathway. Cancer Biol Ther. 2006;5(3): 275-280.

8. Pellicano F, Copland M, Jorgensen HG, Mountford J, Leber B, Holyoake TL. BMS-214662 induces mitochondrial apoptosis in chronic myeloid leukemia (CML) stem/progenitor cells, including CD34+38 cells, through activation of protein kinase C $\beta$. Blood. 2009;114(19): 4186-4196.

9. Sun SY, Liu X, Zou W, Yue P, Marcus AI, Khuri FR. The farnesyltransferase inhibitor lonafarnib induces CCAAT/ enhancer-binding protein homologous protein-dependent expression of death receptor 5, leading to induction of apoptosis in human cancer cells. J Biol Chem. 2007;282(26):18800-18809.

10. Coxon JP, Oades GM, Kirby RS, Colston KW. Zoledronic acid induces apoptosis and inhibits adhesion to mineralized matrix in prostate cancer cells via inhibition of protein prenylation. BJU Int. 2004;94(1): 164-170.

11. Zielinski RR, Eigl BJ, Chi KN. Targeting the apoptosis pathway in prostate cancer. Cancer J. 2013;19(1):79-89.

12. Basu S, Ganguly A, Chakraborty P, et al. Targeting the mitochondrial pathway to induce apoptosis/necrosis through ROS by a newly developed Schiff's base to overcome MDR in cancer. Biochimie. 2012;94(1): 166-183.
13. Sun C, Guo XX, Zhu D, et al. Apoptosis is induced in cancer cells via the mitochondrial pathway by the novel xylocydine-derived compound JRS-15. Int J Mol Sci. 2013;14(1):850-870.

14. Ruvolo PP, Deng X, May WS. Phosphorylation of Bcl2 and regulation of apoptosis. Leukemia. 2001;15(4):515-522.

15. Sepp-Lorenzino L, Tjaden G, Moasser MM, et al. Farnesyl:protein transferase inhibitors as potential agents for the management of human prostate cancer. Prostate Cancer Prostatic Dis. 2001;4(1):33-43.

16. Kurzrock R, Kantarjian HM, Cortes JE, et al. Farnesyltransferase inhibitor R115777 in myelodysplastic syndrome: clinical and biologic activities in the phase 1 setting. Blood. 2003;102(13):4527-4534.

17. Yang HL, Pan JX, Sun L, Yeung SC. p21 Waf-1 (Cip-1) enhances apoptosis induced by manumycin and paclitaxel in anaplastic thyroid cancer cells. J Clin Endocrinol Metab. 2003;88(2):763-772.

18. Tsimberidou AM, Chandhasin C, Kurzrock R. Farnesyltransferase inhibitors: where are we now? Expert Opin Investig Drugs. 2010;19(12): $1569-1580$.

19. Cestac P, Doisneau-Sixou S, Favre G. [Development of farsenyl transferase inhibitors as anticancer agents]. Ann Pharm Fr. 2005;63(1):76-84. French.

20. Pelaia G, Gallelli L, Renda T, et al. Effects of statins and farnesyl transferase inhibitors on ERK phosphorylation, apoptosis and cell viability in non-small lung cancer cells. Cell Prolif. 2012;45(6): 557-565.

21. Singha PK, Pandeswara S, Venkatachalam MA, Saikumar P. Manumycin A inhibits triple-negative breast cancer growth through LC3-mediated cytoplasmic vacuolation death. Cell Death Dis. 2013;4:e457.

22. Balabanov S, Evans CA, Abraham SA, et al. Quantitative proteomics analysis of BMS-214662 effects on CD34 positive cells from chronic myeloid leukaemia patients. Proteomics. 2013;13(1):153-168.

23. Niessner H, Beck D, Sinnberg T, et al. The farnesyl transferase inhibitor lonafarnib inhibits mTOR signaling and enforces sorafenibinduced apoptosis in melanoma cells. J Invest Dermatol. 2011;131(2): 468-479.

24. Liu G, Kelly WK, Wilding G, Leopold L, Brill K, Somer B. An open-label, multicenter, phase I/II study of single-agent AT-101 in men with castrateresistant prostate cancer. Clin Cancer Res. 2009;15(9):3172-3176.

25. Chipuk JE, Fisher JC, Dillon CP, Kriwacki RW, Kuwana T, Green DR. Mechanism of apoptosis induction by inhibition of the antiapoptotic BCL-2 proteins. Proc Natl Acad Sci U S A. 2008;105(51): 20327-20332.

26. Zhang L, Lopez H, George NM, Liu X, Pang X, Luo X. Selective involvement of BH3-only proteins and differential targets of Noxa in diverse apoptotic pathways. Cell Death Differ. 2011;18(5):864-873.

27. Raja Singh P, Arunkumar R, Sivakamasundari V, et al. Antiproliferative and apoptosis inducing effect of nimbolide by altering molecules involved in apoptosis and IGF signalling via PI3K/Akt in prostate cancer (PC-3) cell line. Cell Biochem Funct. Epub August 21, 2013.

28. Sonpavde G, Matveev V, Burke JM, et al. Randomized phase II trial of docetaxel plus prednisone in combination with placebo or AT-101, an oral small molecule Bcl-2 family antagonist, as first-line therapy for metastatic castration-resistant prostate cancer. Ann Oncol. 2012;23(7):1803-1808.
OncoTargets and Therapy

\section{Publish your work in this journal}

OncoTargets and Therapy is an international, peer-reviewed, open access journal focusing on the pathological basis of all cancers, potential targets for therapy and treatment protocols employed to improve the management of cancer patients. The journal also focuses on the impact of management programs and new therapeutic agents and protocols on

\section{Dovepress}

patient perspectives such as quality of life, adherence and satisfaction. The manuscript management system is completely online and includes a very quick and fair peer-review system, which is all easy to use. Visit http://www.dovepress.com/testimonials.php to read real quotes from published authors. 